\title{
factsheet
}

No 37. August 2013

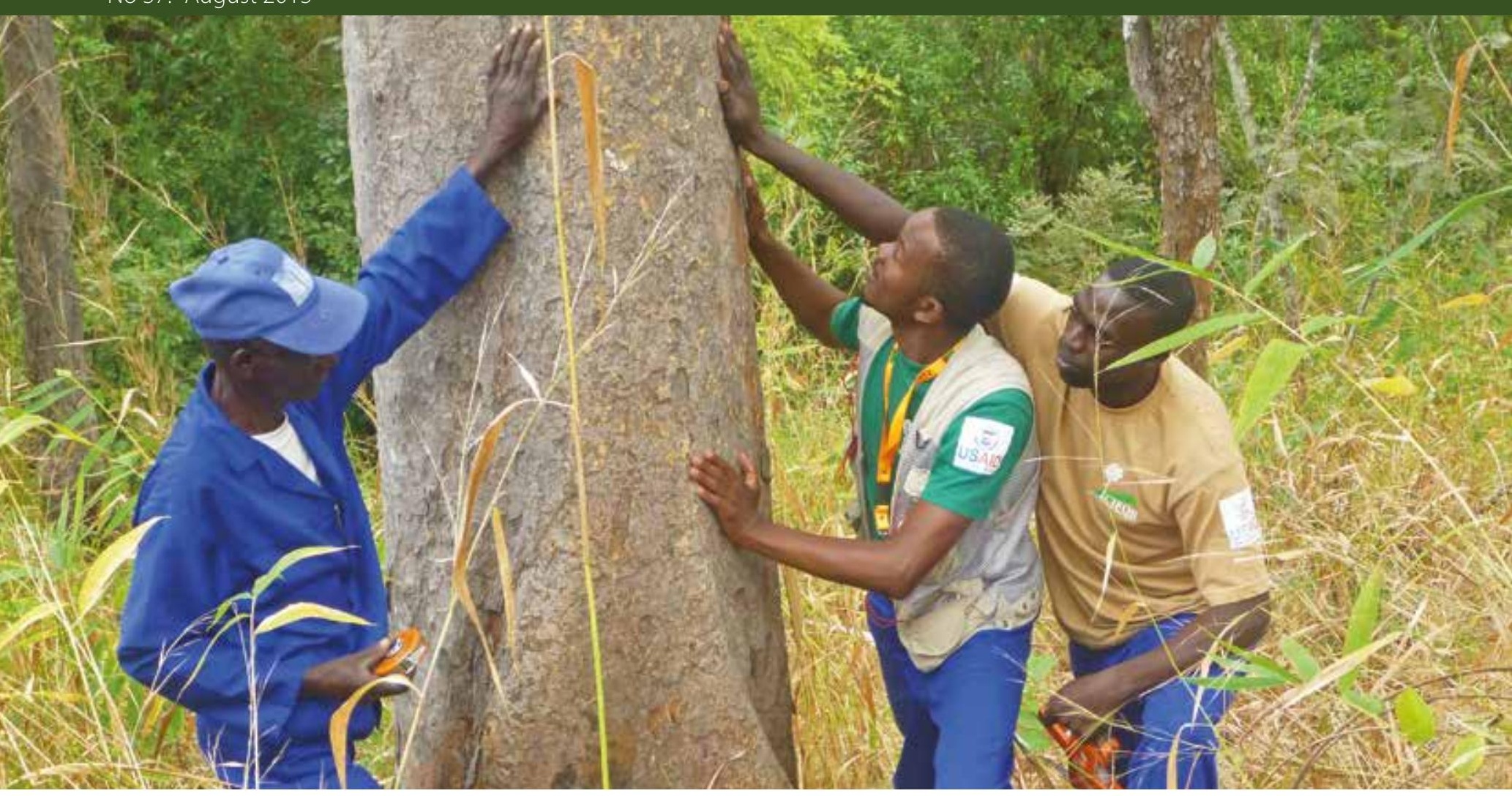

\section{Nyimba forest project}

\section{Background}

Zambia has had one of the highest levels of deforestation in the world, at 250,000 - 300,000 hectares per year according to a 2008 land-use assessment conducted by the Zambian government. Zambian experts estimate that this high rate of deforestation is largely due to smallholder agricultural expansion, infrastructure development and charcoal burning. 'However, the links between these activities, prevailing socio-economic conditions and the monitoring of forest use and impact thereof are not well understood.

Increasingly, the need to address deforestation and forest degradation in countries like Zambia has become a major international issue of concern. To this end, Zambia is one of 16 countries in the world that is engaged in the UN REDD Program. The program aims to prepare countries for future REDD+ implementation through the UN REDD Quick Start Initiative. The output of this initiative will be a National REDD+ Strategy (NRS) for Zambia.

1 The National Joint Program Document, The Government of the Republic of Zambia, 2010.
The US Agency for International Development (USAID) is supporting the Center for International Forestry Research (CIFOR) in Zambia to conduct research and development on models for measuring, reporting and verification (MRV) for REDD+ in the Miombo socio-ecological system, providing key support to Zambia's NRS.

Known as the Nyimba Forest Project, this USD 3.1 million project is a 20-month project that is being implemented from August 2012 to March 2014. The project focuses on Nyimba District in the Eastern Province of Zambia.

\section{Project objectives}

The Nyimba Forest Project aims to generate scientific evidence through in-depth impact-oriented studies that will inform the formulation of Zambia's NRS in alignment with national needs and international standards.

Specifically, the project will generate data and conduct analyses to assist the formulation of Zambia's NRS. In doing so, the project will explain linkages between the direct and underlying drivers of deforestation and forest degradation. 
This will assist the Zambian Government to identify feasible strategies to reduce rates of deforestation and forest degradation that lead to unsustainable forest use, as well as to refine forest monitoring initiatives that include local communities.

Lastly, data and information gathered from the project will be shared with key stakeholders from local to national level so that forest resource users and managers will have deeper understanding of the linkages between forest use and socio-economic conditions.

\section{Project activities}

The Nyimba Forest Project is expected to add value to the NRS and forest monitoring initiatives in Zambia, by providing in-depth studies and socio-economic and biophysical assessments that focus on rural livelihoods, forest resources and traditional forest management strategies.

The project activities include comprehensive reviews and analyses of the National Joint Program document, conducting household surveys, testing communitybased forest monitoring, developing models linking forest resources and forest use with high resolution satellite image data, and establishing dialogue and communications with policy makers and other key stakeholders at all levels.

Through this work, the project is also contributing to the Zambian Forest Department's Integrated Land Use
Assessment by intensifying data collection in Nyimba and providing analyses to assess forest use at local levels.

\section{Partners}

The Nyimba Forest Project is a partnership program that engages government agencies at the district and national level, local communities in Nyimba District, universities and nongovernment organizations (NGOs).

At the implementation level, CIFOR works collaboratively with Zambia's Forest Department, Zambia Wildlife Authority, COMACO, Community Youth Concern and the District Women's Association.

\section{Contact}

Center for International Forestry Research (CIFOR)

C/O Forestry Nursery Site, 4019 Elm Road,

Woodlands, Lusaka, Zambia

Tel +260211266864

Fax +260211265885

This publication is made possible by the generous support of the American people through the U.S. Agency for International Development (USAID). The contents of this publication are the sole responsibility of CIFOR and do not necessarily reflect the views of USAID or the U.S. government.

\begin{tabular}{|c|c|c|}
\hline CGIAR & $\begin{array}{l}\text { RESEARCH } \\
\text { PROGRAM ON } \\
\text { Forests, Trees and } \\
\text { Agroforestry }\end{array}$ & $\begin{array}{l}\text { This research was carried out by CIFOR as part of the CGIAR Research Program on Forests, Trees and } \\
\text { Agroforestry (CRP-FTA). This collaborative program aims to enhance the management and use of forests, } \\
\text { agroforestry and tree genetic resources across the landscape from forests to farms. CIFOR leads CRP-FTA in } \\
\text { partnership with Bioversity International, CIRAD, the International Center for Tropical Agriculture and the } \\
\text { World Agroforestry Centre. }\end{array}$ \\
\hline
\end{tabular}

